\title{
The Experience and Enlightenment of American High-End Equipment Manufacturing Industry to China*
}

\section{Ying Chi, Jianming Zhang}

School of Management, Shanghai University of Engineering Science, Shanghai, China.

Email: yczjut@126.com

Received October $26^{\text {th }}, 2013$; revised November $26^{\text {th }}, 2013$; accepted December $2^{\text {nd }}, 2013$

Copyright (c) 2013 Ying Chi, Jianming Zhang. This is an open access article distributed under the Creative Commons Attribution License, which permits unrestricted use, distribution, and reproduction in any medium, provided the original work is properly cited. In accordance of the Creative Commons Attribution License all Copyrights (C) 2013 are reserved for SCIRP and the owner of the intellectual property Ying Chi, Jianming Zhang. All Copyright (C) 2013 are guarded by law and by SCIRP as a guardian.

\begin{abstract}
To get rid of the financial crisis happened in 2008, the United States, as the representative of developed countries, made an achievement of the transformation from the "de-industrialization" to "re-industrialization". The US government took some effective measures through the combination of government, R \& D and production, such as focusing on high-end equipment manufacturing industry, increasing R \& D investment, encouraging innovation actively, building competitive markets, paying attention to the multinational industrial reflux and vigorously supporting the SME, to develop high-end equipment manufacturing industry. Learning from the experience of the United States, China should take some effective measures. Firstly, our country should increase the investment in scientific research, in particular by increasing funding for basic research, and then by improving innovation capabilities. Secondly, our country should vigorously support the SME and improve the employment situation. Finally, our country needs to further maintain and improve the socialist market economic system.
\end{abstract}

Keywords: High-End Equipment Manufacturing Industry; Government; R \& D; Product; Market

\section{Introduction}

High-end equipment manufacturing industry is the future direction of global manufacturing. To get rid of the financial crisis happened in 2008, the United States, as the representative of developed countries, made an achievement of the transformation from the "de-industrializetion" to "re-industrialization" and carried out a series of policies including "AMP”(Advanced Manufacturing Partnership) and "American Recovery and Reinvestment Act”.

At present, China has become the largest equipment manufacturing country in the world, but still "big not strong." It is the key breakthrough to achieve the transformation from "Made in China" to "Created in China" for developing the high-end equipment manufacturing. But how can we realize it? The US experience in the de-

*Fund: The research project of Shanghai soft science research base in 2013: Building competitiveness research framework of strategic emerging industries-taking new energy automobile industry as an example in Shanghai science and technology innovation and public management research center (13692180600). velopment of high-end equipment manufacturing industry must be a certain reference for our country. This paper will focus on the US high-end equipment manufacturing industry, its developing experience and analyses how China should develop high-end equipment manufacturing industry.

\section{Developing the High-End Equipment Manufacturing Industry in the United States and China}

The United States is one of the most developed countries whose equipment manufacturing industry is well-developed. But since the 1970s, in order to solve the problem of economic stagnation, the United States achieved economic "de-industrialization" through international Industrial transfer [1]. The US began to focus on the "FIRE" industries, namely finance, insurance and real estate [2]. The implementation of "de-industrialization" solved the employment problems of the American people to a certain extent. Because from 1980 to 2010, although the numbers of manufacturing employees in the US drop- 
ped by nearly 9 million, the total number of employees and employment rate were gradually rising. In 1982, the US unemployment rate reached a peak of $9.708 \%$. In 1997, the US unemployment rate fell to $4.942 \%$, which was the first time less than $5 \%$ since 1980. In the following 10 years, this data has been maintained between $4 \%$ to $6 \%$ stably. When the shortcomings of the virtual economy exposed, the US unemployment rate suddenly increased during the financial crisis. In 2008, the US unemployment rate was $5.8 \%$. And in 2009, it rose to $9.275 \%$, rising by as much as $59.91 \%$ (As shown in Figure 1).

The weakening of the real economy, represented by manufacturing, is the main reason for high unemployment in America. In the past 15 years, the American manufacturing output accounted for $20 \%$ of the world (As shown in Figure 2). However, according to the analysis of the growth proportion of manufacturing output, the speed of development of American manufactur- ing is similar with world average level (As shown in Figure 3). What is more, the US manufacturing output as a proportion of GDP is far below world average level (As shown in Figure 4). It is obvious that the "de-Industrialization" should take responsibility for both financial crisis and individual employment issues. Therefore, revitalizing the manufacturing is the top priority of the US government. As a country with advantages of excellent basic research and manufacturing technology, the United States should focus on developing high-end areas of manufacturing.

On November 2th, 2009, American President Barack Obama issued a statement that the US economy would turn to sustainable growth model. It was a signal that the US economy would back to the real economy. Up to December, 2012, American manufacturing output has been greatly improved and the unemployment rate has fallen to $8.2 \%$ (As shown in Figure 1). According to the achievement the US made after the release of "re-in-

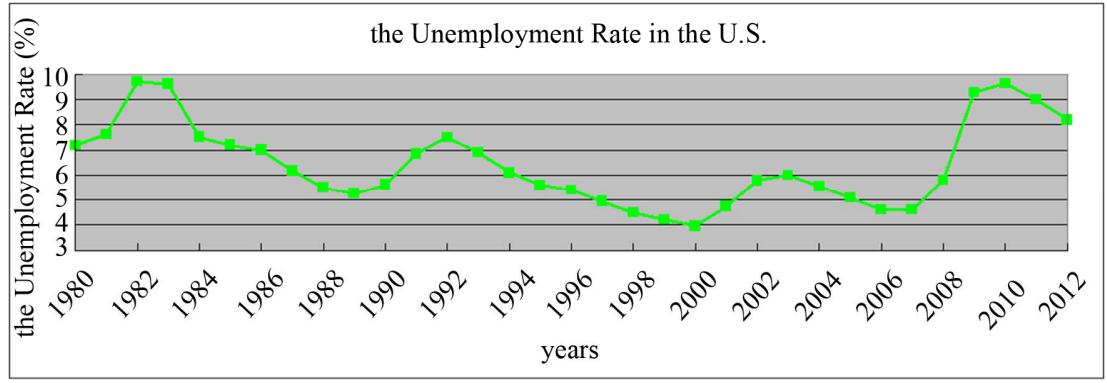

Figure 1. The unemployment rate in the US [3].

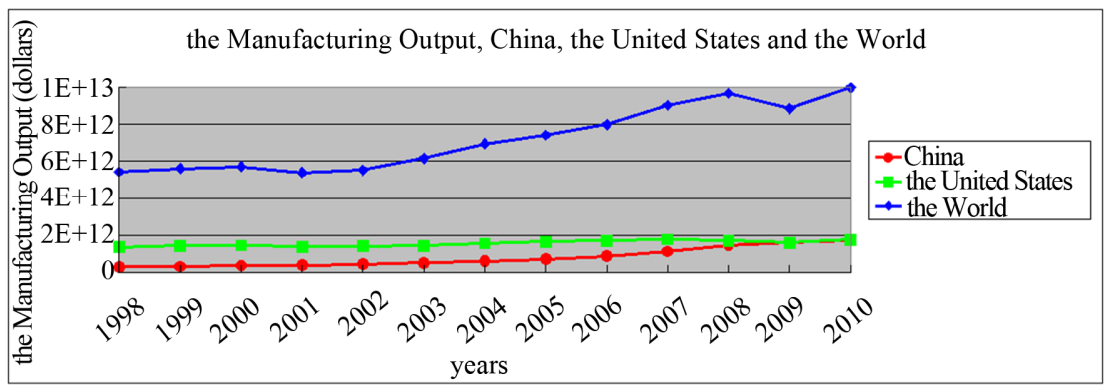

Figure 2. The manufacturing output, China, the United States and the World [4].

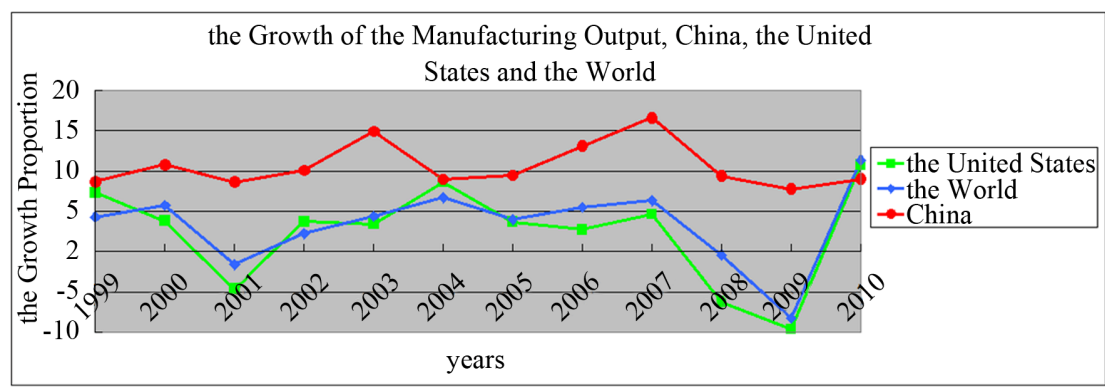

Figure 3. The growth of the manufacturing output, China, the United States and the World [4]. 


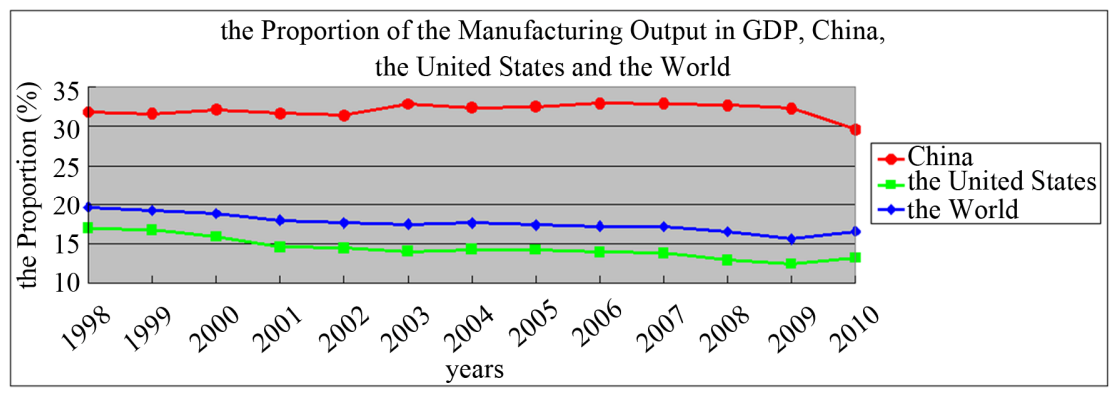

Figure 4. The proportion of the manufacturing output in GDP, China, the United States and the World [4].

dustrialization" concept, we have no reason to doubt that "re-industrialization" in the United States is a long-term strategy. However, it is noteworthy that the "re-industrialization" concept now is not the same as before. This time, the aim of the release of "re-industrialization" concept is to ensure their "engine" status of world economy and to capture domestic competitive advantage in advanced manufacturing. America has the world's most advanced basic research laboratories, excellent technical innovation and world-class schools and research institutions, which are the basis of developing high-end equipment manufacturing industry. What is more, the United States has a lot of multinationals as strong support. And there are 160 American companies in the Fortune 500 companies.

With the advantages of large population and cheap labor, China has become the largest equipment manufacturing country in the world. However, compared with the United States, the most obvious characteristic of the China's manufacturing equipment manufacturing is "big not strong”. So our country also should focus on developing high-end areas of manufacturing.

\section{The Experience of American High-End Equipment Manufacturing Industry}

The United States has the strongest manufacturing competitiveness in the world with the model of "R \& D and production-Export-Import" [5]. It keeps the first-class level of scientific research and development in order to make more competitive new products all the time. When the new products are sold in the domestic market, they will soon be extended to the international market. Production and sales in developing countries bring down the cost, the United States can give up the production of such products in favor of imports from abroad and turn to research more high-end products. A new round circulation is beginning, which is so called the international Industrial transfer.

The market economic system in the United States is sound relatively, but the lack of government intervention will still lead to some problems. Therefore, in the process of developing the high-end equipment manufacturing industry, the United States doesn't only rely on its market, but also pays attention to the role of the government. Basing on the market economic system, the United States combines the government, basic research and production to develop high-end equipment manufacturing industry (As shown in Figure 5), the followings are some of the specific measures.

First of all, paying attention to the high-end equipment manufacturing industry. In 2009, in order to seize the new round of the commanding heights of science and technology and industrial competitiveness, the US government put forward the "re-industrialization" concept, to ensure their "engine" status of world economy and to capture domestic competitive advantage in advanced manufacturing. In the same year, the United States released "A Strategy for American Innovation: Driving towards Sustainable Growth and Quality Jobs” [6]. The report highlighted that the development of some key areas, such as advanced automotive manufacturing technology, also marks the return of the real economy. In order to develop high-end equipment manufacturing industry, the United States has issued a series of policies, including the "Advanced Manufacturing Partnership” [7] and the "2009 American Recovery and Reinvestment Act” [8]. The formation of new concepts is an important symbol that indicates the US attach importance to manufacturing industry again, especially high-end equipment manufacturing. And followed new policies are the implementation of these concepts. Besides, a lot of capital investment also indicates that the US government attaches great importance to high-end equipment manufacturing.

Secondly, increasing investment in R \& D and actively encouraging innovation. Depending on the development model of traditional manufacturing of America, R \& D is the first element. R \& D is the basis of technical innovation and technological innovation is one of the purposes of R \& D. And they are often complementary and inseparable. Over the past few years, the EU attaches great importance to technological innovation, but the effect is very general. It is mainly because of the lack of invest- 


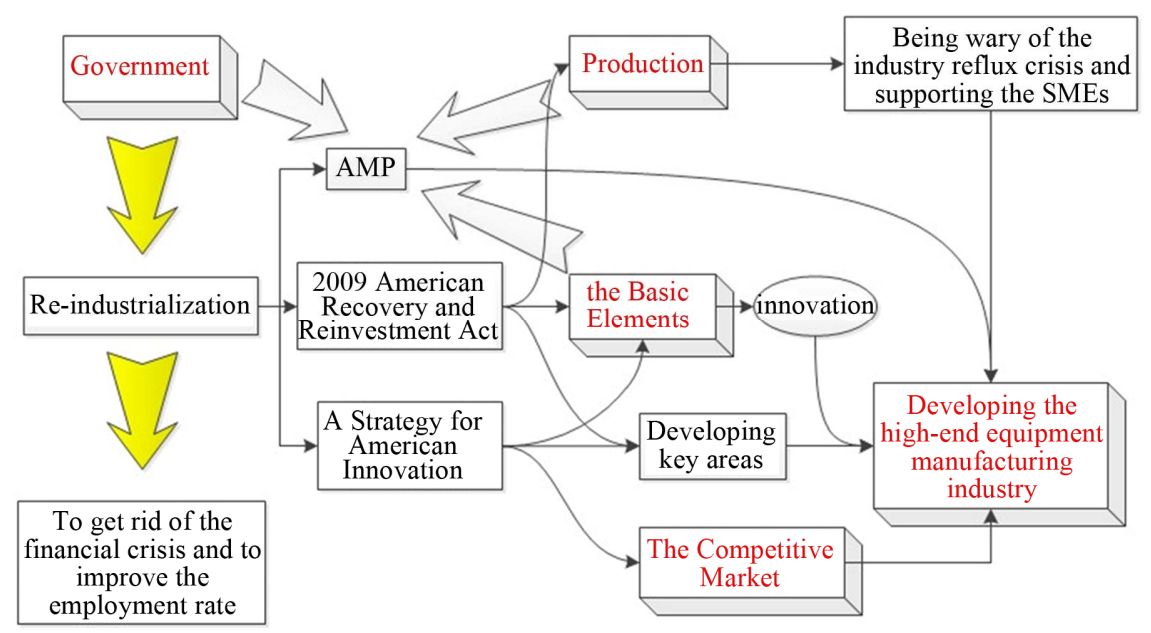

Figure 5. The experience of american high-end equipment manufacturing industry.

ment in basic research. However, the US government do not make such a mistake, they actively encourage innovation on the basis of increasing investment in $\mathrm{R} \& \mathrm{D}$ instead. In February, 2009, the 111th United States Congress jointly developed a series of economic recovery plan, which includes the "2009 American Recovery and Reinvestment Act”. On February 17th, US President Barack Obama signed it as the law. "2009 American Recovery and Reinvestment Act” indicates that the total cost of a series of economic recovery plan over the period from 2009 to 2019 is about $\$ 787$ billion, which increased to $\$ 831$ billion later. In addition, the US government intends to invest $\$ 7.6$ billion directly into scientific research, which includes $\$ 3$ billion into the US National Science Foundation, \$2 billion to the US Department of Energy and \$1 billion to the US National Aeronautics and Space Administration. It is clear that the US government attaches great importance to $\mathrm{R} \& \mathrm{D}$. In September, 2009, the United States released "A Strategy for American Innovation: Driving Towards Sustainable Growth and Quality Jobs”. And the report indicates that the US is working on restoring the leading position in basic research. Over the past 40 years, funds invested in physics, mathematics and engineering by the federal government in the percentage of GDP decreased by almost half, that is, from $0.25 \%$ down to $0.13 \%$. To this end, the US government plans to invest 3\% of GDP for research and development, and proposed to double the budget of some key institutions, such as the National Science Foundation, the Scientific Office of Department of Energy and the like. These plans lay a solid foundation for the development of new industries and creating jobs.

Thirdly, fostering the competitive markets. America has been adopted the market economy, but the blindness of the market is also one of the reasons leading to the financial crisis. Therefore, some people believe that the gov- ernment must play a leading role and protect some key areas. However, this argument is not correct. Because selecting winners entirely through the government-controlled will lead to a waste of resources and the government's decision-making capacity is limited." A Strategy for American Innovation" emphasizes the importance of a competitive market. And it also emphasizes that the United States should support a competitive market, which is not only open, but also able to allocate resources to enterprises which have the innovative capability. The United States recognizes not only the importance of public support for developing high-end equipment manufacturing industry, but also the harm of excessive government intervention.

Fourthly, the multinational industrial backflow and vigorously supporting the SME. In 2011, the world-famous Boston Consulting Group released a report called "Made in America again-—why manufacturing Industry will flow back to the US” The report presents two trends of the future: the first one is that the high value-added and high-tech equipment manufacturing industry will return to the US native, the second is the flow of labor-intensive manufacturing from China to developing countries having lower cost. By the way, high value-added and high-tech equipment manufacturing industry is the high-end equipment manufacturing Industry we discussed. It is clear that the United States is able to develop high-end equipment manufacturing industry only through the industrial backflow. A recent research shows that $1 / 3$ of manufacturing companies headquartered in the United States intend to return production from China to America. It is worth noting that most companies' annual sales are more than $\$ 1$ billion. Although a large-scale backflow has not yet formed, the trend of backflow is very clear. In spite of the fact that American the SME' influence are far less than multina- 
tional corporations', American the SME still play their own role as an important part of the industry chain and have a large proportion (99.7\% of total enterprises and $40 \%$ of total enterprise revenue). In March, 2009, the US government used $\$ 730$ million to address the lending problem of small businesses. On December 11th, 2009, the US government used the remaining funds of Troubled Asset Relief Program to support small businesses.

Finally, paying attention to a combination of the government, basic R \& D and production. In the general background of market-oriented, the inevitable processes of developing high-end equipment manufacturing include forming new concepts, releasing policies supported by government and funding, doing scientific research and technological innovation, producing parts of the SME and integrating multinationals. In short, the United States has a perfect combination of the government, basic R\&D and production. "Advanced Manufacturing Partnership" recently proposed by Obama is a program to invest and promote the development of emerging technologies which was jointly discussed by industry, universities and the federal government.

\section{The Enlightenment of American High-End Equipment Manufacturing Industry to Our Country}

As a late-developing country, China has to face to a great number of problems as weak economic foundation, poor environment and few resources while developing the high-end equipment manufacturing industry. So it is hard to copy the American model of " $\mathrm{R} \& \mathrm{D}$ and production-Export-Import”. Under the background of market economy system, the United States paid more attention to the high-end equipment manufacturing industry, increased R \& D investment, encouraged innovation actively, increased the industry reflow and supported the SME after the 2008 financial crisis. In order to well develop the high-end equipment manufacturing industry, A series of measures has been taken to achieve the combination of the government, R \& D and production, which is worth our reference.

Firstly, the government decides the direction of the high-end equipment manufacturing industry development. In the past 15 years, the manufacturing output of the United States, as the representative of developed countries, went up steadily keeping pace with the world. However, in 2008 and 2009, we could see significant negative growth. Compared with developed countries, China's manufacturing output increased rapidly, and it was not influenced greatly by the global financial crisis in 2008. It has been proved that the concept of "paying attention to manufacturing" make our country get away from the financial crisis (As shown in Figures 2 and 3).
In the past 15 years, the world's proportion of manufacturing output in GDP remained at $15 \%$ to $20 \%$. However, before 2008, under the guidance of the "de-industrializetion", the proportion of the United States was going down slightly year by year. After 2008, with the new idea of "re-industrialization" being recognized steadily, the situation began to get well. In contrast, China's proportion of manufacturing output in GDP is much higher than the average in the world(As shown in Figure 4). Our government always pays high attention to the equipment manufacturing industry. The State Council promulgated the "twelfth 5 years plan in national strategic emerging industry development" and the "twelfth 5 years plan in high-end equipment manufacturing industry development" to accelerate the development of the highend equipment manufacturing industry.

Secondly, R \& D is the basis for the development of high-end equipment manufacturing industry. In the last 20 years, the R \& D expenditures in China increased year by year, so did its proportion in GDP. In 1993, the R \& D expenditures in China was about 19.6 billion yuan accounting for $0.62 \%$ of GDP; In 2011, it was up to 868.7 billion yuan accounting for $1.84 \%$ of GDP (As show in Figure 6). The report of "Science and engineering indicators 2012" implied that China's investment in scientific research had surpassed Japan, which was in the second place after the United States. Nevertheless, It was still far away from the United States' target that the proportion of R \& D expenditures in GDP would be up to $3 \%$, so it is necessary for us to increase our investment in research. In addition, the proportion of China's basic research funding in the total R \& D expenditure was only $4.74 \%$ in 2011, while the data of the United States was up to $20 \%$. Besides, the innovation capability of the manufacturing industry is weak in China, there is a variety of fake goods. Therefore, if China wants to develop high-end equipment manufacturing industry, the first task is to further increase investment in scientific research, especially for the basic research. Under this background, we can increase our innovation capability and reduce fake goods.

Thirdly, the production is another important part. As is mentioned, in order to solve their own economic development issues, there will be two measures be taken in the United States. One is that the high value-added, hightech equipment manufacturing industry will return to the mainland, and the second is that the labor-intensive manufacturing will flow from China to lower cost developing countries. Both 2 measures will strike our manufacturing industry. It means that China's existing high-end equipment manufacturing industry will not be able to get the support of foreign advanced technology. Coupled with our weak scientific and technological in- 


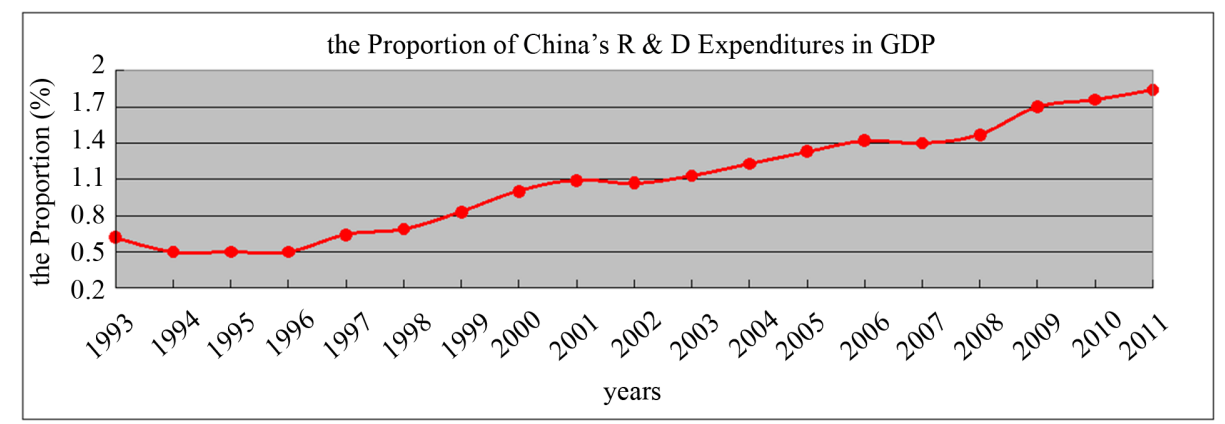

Figure 6. The proportion of China's R \& D expenditures in GDP [9].

novation, future developments in the field of high-end equipment manufacturing industry are not optimistic. The flow of labor-intensive manufacturing from China to lower cost countries will weaken our advantage that China has a large population. Therefore, the Government should support the SME in some key areas to help them achieve industrialization.

Finally, the market is the core of the development of high-end equipment manufacturing industry. The United States caused the world financial crisis, and the government has already taken a series of measures which include "heavily bailout". Although some people think that it is a great irony of the market economy, this argument is obviously not correct. Because introduction of government policy and capital investment does not affect the nature of the market economic, and the US market still has a high degree of freedom and competition. Because the United States has a relatively complete market economic system, it is more important for the government to play a role in promoting. Compared with America, our government has played a significant role, so paying attention to market-oriented trend is more important for developing high-end equipment manufacturing industry. The report of the 18th CPC National Congress pointed out that the core problem of economic reform is to deal with the relationship between the government and the market. Besides, it is necessary to respect the laws of the market and make the government play a better role. To make the market to play a fundamental role in the economic system, strictly controlling excessive government intervention to market economy is urgent. China should unswervingly promote reform and adhere to market-oriented economic system. Functions of the government should proceed to create a fair competitive market rules and institutions and to provide infrastructure and basic research and development funds for the market. Only through this method can a market-based economy which has government involvement in macro economy be established. And this economic system is able to create good environment for developing high-end equipment manufacturing industry.

\section{Conclusion}

Compared with the development of the high-end equipment manufacturing industry in the United States, there are still many deficiencies in our country. We have some suggestions to solve them: firstly, increasing investment in scientific research, especially for the basic research; secondly, being wary of the industry reflux crisis caused by the developed countries and supporting the SME in some key areas to help them achieve industrialization. The most important thing is that China needs to further improve the socialist market economy system and pay more attention to the market itself, in order to develop the high-end equipment manufacturing industry better.

\section{REFERENCES}

[1] Y.-M. PU, "Adjustment of Industrial Structure and American Industrialization,” Journal of Guizhou Normal University (Social Science), Vol. 6, 2002, pp. 44-49.

[2] L.-C. Guo, Y.-W. Xu and X. Wang, "The International Industrial Transfer and the Industrial Restructuring in USA and EU," Research on Financial and Economic Issues, Vol. 10, 2012, pp. 97-103.

[3] “United States Unemployment Rate,” 2013. http://www.indexmundi.com/united_states/unemployment _rate.html

[4] The World Bank, 2013. http://data.worldbank.org/

[5] W.-Q. Zhang and S.-J. Li, "Building a World-Class Equipment Manufacturing Base-Strategic Positioning and Development Path,” China Economic Publishing House, Beijing, 2011.

[6] Obama, “A Strategy for American Innovation: Driving Towards Sustainable Growth and Quality Jobs”.

[7] Obama, “Advanced Manufacturing Partnership”.

[8] 2013. http://en.wikipedia.org/wiki/American_Recovery_and_Re investment_Act\#Scientific_research

[9] China Yearbook. 